We conclude that atrial natriuretic peptide can induce a gradual decrease in blood pressure, sometimes followed by symptomatic hypotension, which occurs suddenly. This phenomenon depends on the duration of the infusion as well as the dose. Moreover, the dose effect is enhanced during low sodium intake. This warrants careful observation of patients with essential hypertension who are given infusions of atrial natriuretic peptide over longer periods.

We thank M J Gomez and E S Otterbein from Merck, Sharp, and Dohme Research Laboratories for their support.

\section{References}

1 Richards AM, Nicholls MG, Ikram H, Webster MWI, Yandle TG, Espiner EA. Renal haemodynamic, and hormonal effects of human alpha atrial natriuretic peptide in healthy volunteers. Lancet 1985 ; i:545-9.

2 Tikkanen I, Fyhrquist F, Metsrinne K, Leidenius R. Plasma atrial natriuretic peptide in cardiac disease and during infusion in healthy volunteers. Lancet 1985;ii:66-9.

3 Espiner EA, Crozier IG, Nicholls MG, Cuneo R, Yandle TG, Ibram H. Cardiac secretion of atrial natriuretic peptide. Lancet 1985;ii:398-9.

4 Volpe M. Odell G, Kleinert HD, et al. Effect of atrial natriuretic factor on blood pressure, renin and aldosterone in Goldblatt hypertension. Hypertension 1985;7:143-8.

Ackermann U, Irizawa TG, Milojevic S, Sonnenberg $\mathrm{H}$. Cardiovascular effects of atrial extracts in anesthetized rats. Can f Physiol Pharmacol 1984;62:819-22.

(Accepted 8 May 1986)

\title{
The effect of desmopressin on nocturnal polyuria, overnight weight loss, and morning postural hypotension in patients with autonomic failure
}

\author{
CHRISTOPHER J MATHIAS, PAUL FOSBRAEY, \\ DAVID F DA COSTA, \\ ANDREW THORNLEY, ROGER BANNISTER
}

\begin{abstract}
Day and night urine volume, morning and evening body weight, and supine and sitting blood pressure were measured in five patients with chronic autonomic failure who were not receiving treatment with drugs. All had nocturnal polyuria, overnight weight loss, and a pronounced postural fall in blood pressure, with lowest levels in the morning. Desmopressin (2-4 $\mu \mathrm{g}$ given intramuscularly at $8 \mathrm{pm}$ ) reduced nocturnal polyuria, diminished overnight weight loss, raised supine blood pressure, and reduced the postural fall, especially in the morning, when patients were often at their worst.

Desmopressin may be a useful alternative to, or may supplement, other forms of treatment in some patients with autonomic failure.

\section{Introduction}

Patients with autonomic failure often find that their symptoms of postural hypotension are worse in the morning. Their blood pressure is often lowest at this time ${ }^{1}$ and this may be related to nocturnal polyuria, which probably reduces the volume of extracellular fluid. To investigate this we studied patients before and after reversal of nocturnal polyuria with an antidiuretic agent, desmopressin.
\end{abstract}

\section{Patients and methods}

Six patients with progressive autonomic failure (four men and two women, aged between 55 and 68 ) were studied; two also had multiple system

\footnotetext{
Medical Unit, St Mary's Hospital Medical School, Paddington, London W2 IPG and University Department of Clinical Neurology, Institute of Neurology, Queen Square, London

CHRISTOPHER J MATHIAS, DPHIL, MRCP, Wellcome senior lecturer in medicine and honorary consultant physician

PAUL FOSBRAEY, PHD, research assistant

DAVID F DA COSTA, MRCP, research fellow

ANDREW THORNLEY, MSC, research assistan

SIR ROGER BANNISTER, DM, FRCP, consultant neurologist

Correspondence to: Dr Mathias, St Mary's Hospital Medical School.
}

atrophy. ${ }^{2}$ All had severe sympathetic failure and symptomatic postural hypotension. Drugs (fludrocortisone acetate and ephedrine) had been withdrawn three days previously. Their intake of fluid and food was unrestricted, and they maintained their normal level of mobility. Urine was collected over periods of 12 hours ( $9 \mathrm{am}$ to $9 \mathrm{pm}$ and $9 \mathrm{pm}$ to $9 \mathrm{am}$ ), and volume, osmolality, and excretion of sodium and potassium were measured. Patients were weighed at 9 am and $9 \mathrm{pm}$. Blood pressure (mercury sphygmomanometer) and heart rate (radial pulse) were measured after the patients had been supine for at least 10 minutes and after they had been sitting on the edge of the bed for two minutes. Standing blood pressure was not recorded because some found it difficult to stand, particularly in the morning. Measurements were taken before meals to avoid postcibal hypotension. ${ }^{3}$ On the third day haemoglobin concentration, packed cell volume, blood urea, plasma sodium and potassium concentrations, and plasma osmolality were measured. After three control days the observations were repeated, with the addition of $2 \mu \mathrm{g}$ desmopressin given intramuscularly at $8 \mathrm{pm}$ on the first night, followed by $4 \mu \mathrm{g}$ for two further nights. Blood measurements were repeated after three days' treatment with desmopressin. Patients then either restarted their previous treatment or entered a pilot study to determine a beneficial therapeutic dose of intranasal desmopressin. Five patients who completed the study are analysed here as a group and one patient is discussed separately as she developed hyponatraemia. Paired and unpaired $t$ tests were used for statistical analysis. Results are expressed as means (SEM)

\section{Results}

\section{CONTROL PERIOD}

All patients had nocturnal polyuria, with an overnight excess of 169 (79) $\mathrm{ml}$ (table I). Overnight weight loss was $0.74(0.07) \mathrm{kg}(\mathrm{p}<0.01)$. Nocturnal urinary sodium concentration was greater $(p<0.05)$ and urinary osmolality was lower than during the day. Supine blood pressure was lowest in the morning and rose during the day (table II). The postural fall in blood pressure on sitting was similar in the morning and evening, but symptoms were worse in the morning, probably because supine blood pressure was lower.

\section{DESMOPRESSIN PERIOD}

After treatment with desmopressin there was a pronounced reduction in nocturnal polyuria $(p<0.01)$ (see table I) and overnight weight loss was reduced. Body weight rose by $1.35(0.06) \mathrm{kg}(\mathrm{p}<0.01)$ over three days. Supine blood pressure was higher in the morning (see table II), when the postural fall was maximally reduced $(p<0.05)$. Sitting blood pressure improved during the day. Overnight urinary osmolality was higher $(p<0.05)$ 
TABLE I-Mean (SEM) urine volumes, 12 hourly excretion of sodium and potassium, and urinary osmolality in five patients during three control days and three days of treatment with desmopressin

\begin{tabular}{|c|c|c|c|c|c|}
\hline & $\begin{array}{l}\text { Volume } \\
\quad(\mathrm{ml})\end{array}$ & $\begin{array}{l}\text { Urinary } \\
\text { sodium } \\
(\mathbf{m m o l})\end{array}$ & $\begin{array}{l}\text { Urinary } \\
\text { potassium } \\
(\mathrm{mmol})\end{array}$ & $\begin{array}{c}\text { Urinary } \\
\text { osmolality } \\
(\mathrm{mmol} / \mathrm{kg})\end{array}$ & $\begin{array}{c}\text { Body } \\
\text { weight* } \\
(\mathrm{kg})\end{array}$ \\
\hline $\begin{array}{l}\text { Control period } \\
\text { Desmopressin period }\end{array}$ & $\begin{array}{l}698(140) \\
802(241)\end{array}$ & $\begin{array}{c}\text { Day } \\
60(10) \\
102(22)\end{array}$ & $\begin{array}{l}30(4) \\
31(4)\end{array}$ & $\begin{array}{l}481(68) \\
621(68)\end{array}$ & $\begin{array}{l}71 \cdot 7(5 \cdot 6) \\
72 \cdot 8(5 \cdot 5)\end{array}$ \\
\hline $\begin{array}{l}\text { Control period } \\
\text { Desmopressin period }\end{array}$ & $\begin{array}{ll}867 & (50) \\
498 & (39)\end{array}$ & $\begin{array}{c}\text { Night } \\
94(11) \\
100(15)\end{array}$ & $\begin{array}{l}39(3) \\
25(2)\end{array}$ & $\begin{array}{l}401(52) \\
691(47)\end{array}$ & $\begin{array}{l}71 \cdot 0(5 \cdot 5) \\
72 \cdot 6(5 \cdot 5)\end{array}$ \\
\hline
\end{tabular}

* Measured at end of day and night periods ( $9 \mathrm{pm}$ and $9 \mathrm{am}$, respectively).

Conversion: SI to traditional units-Sodium: $1 \mathrm{mmol}=1 \mathrm{mEq}$. Potassium: $1 \mathrm{mmol}=1 \mathrm{mEq}$ Osmolality: $1 \mathrm{mmol} / \mathrm{kg}=1 \mathrm{mosmol} / \mathrm{kg}$. of fluid overload, suggesting that these patients have chronic fluid depletion. This supports the observation that patients with autonomic failure have an impaired ability to conserve salt and water as they lose weight and their blood pressure falls when their intake of salt is restricted; there is, however, no firm evidence of a mineralocorticoid deficiency, and their renal responses are only partially rectified by fludrocortisone.

The mechanisms accounting for diuresis and natriuresis induced by recumbency may include resistance to mineralocorticoids, inappropriate secretion of vasopressin, ${ }^{8}$ increased renal perfusion from a rise in blood pressure, and release of atrial natriuretic peptides. ${ }^{9}$ Whatever the reasons, our patients' nocturnal polyuria was reduced by modest doses of desmopressin and their blood pressure improved. Desmopressin did not, however, reduce the

TABLE II-Mean (SEM) lying and sitting blood pressures and heart rates in five patients at different times of day during three control days and three days of treatment with desmopressin

\begin{tabular}{|c|c|c|c|c|}
\hline & $6 \mathrm{am}$ & $12 \mathrm{pm}$ & $6 \mathrm{pm}$ & $10 \mathrm{pm}$ \\
\hline \multicolumn{5}{|l|}{ Control period } \\
\hline Lying blood pressure $(\mathrm{mm} \mathrm{Hg})$ & $127(6) / 80(3)$ & $145(9) / 89(5)$ & $145(10) / 83(3)$ & $140(7) / 87(3)$ \\
\hline Lying heart rate (beats/minute) & $75(3)$ & $67(3)$ & $70(5)$ & 71 (3) \\
\hline Sitting blood pressure $(\mathrm{mm} \mathrm{Hg})$ & $101(7) / 65(6)$ & $111(9) / 70(5)$ & $115(10) / 68(7)$ & $116(10) / 76(5)$ \\
\hline Sitting heart rate & & & & \\
\hline (beats/minute) & $74(6)$ & $71(4)$ & $73(4)$ & $77(5)$ \\
\hline \multicolumn{5}{|l|}{ Desmopressin period } \\
\hline Lying blood pressure ( $\mathrm{mm} \mathrm{Hg}$ ) & $136(9) / 85(5)$ & $132(11) / 82(6)$ & $141(10) / 84(4)$ & $140(8) / 85(4)$ \\
\hline Lying heart rate (beats $/$ minute) & 73 (2) & $69(4)$ & $70(6)$ & $73(4)$ \\
\hline Sitting blood pressure $(\mathrm{mm} \mathrm{Hg})$ & $116(15) / 78(9)$ & $121(9) / 76(6)$ & $123(12) / 79(5)$ & $123(9) / 81(3)$ \\
\hline \multicolumn{5}{|l|}{ Sitting heart rate } \\
\hline (beats/minute) & $74(5)$ & $73(5)$ & $72(6)$ & $75(3)$ \\
\hline
\end{tabular}

after desmopressin, but sodium excretion remained unchanged. Daytime urinary sodium excretion and osmolality both increased (both $\mathrm{p}<0.05$ ).

Potassium excretion was unchanged.

After treatment with desmopressin there was a small fall in all plasma measurements. Haemoglobin concentration fell from 123 (7) to 120 (11) g/l, packed cell volume from $0.37(0.2)$ to $0.35(0.03)$, sodium concentration from $141(0 \cdot 2)$ to $136(2 \cdot 0) \mathrm{mmol}(\mathrm{mEq}) / \mathrm{l}$, potassium concentration from $4 \cdot 2(1.0)$ to $3.9(0 \cdot 1) \mathrm{mmol}(\mathrm{mEq}) / \mathrm{l}$, urea concentration from $7 \cdot 2(1 \cdot 0)$ to $6.4(1.0) \mathrm{mmol} / \mathrm{l}(43 \cdot 2(6 \cdot 0)$ to $38.4(6.0) \mathrm{mg} / 100 \mathrm{ml})$, and osmolality from 293 (5) to 276 (3) $\mathrm{mmol}(\mathrm{mosmol}) / \mathrm{kg}$. Only the fall in osmolality was significant $(\mathrm{p}<0.05)$.

The five patients who completed the study telt considerably better when receiving treatment with desmopressin. They were more comfortable at night because nocturia was either reduced or abolished and had fewer postural symptoms during the day, especially in the morning. None complained of untoward side effects. In one patient treatment with desmopressin improved blood pressure, but she passed no urine on the second night and $500 \mathrm{ml}$ during the next day. She complained of headache, restlessness, and nausea, which suggested water intoxication. Fluid intake had not changed but her weight rose from 48.4 to $50.6 \mathrm{~kg}$. Her plasma sodium concentration fell to $123 \mathrm{mmol}(\mathrm{mEq}) / \mathrm{l}$, and the plasma was hypotonic at $250 \mathrm{mmol}(\mathrm{mosmol}) / \mathrm{kg}$. Treatment with desmopressin was stopped and fluid restriction was enforced, with the symptoms abating and biochemical values returning to normal after two days.

\section{Discussion}

In our patients recumbency caused nocturnal polyuria and an overnight weight loss, which was greater than in similarly aged normal subjects. ${ }^{4}$ This probably reduced extracellular fluid volume and contracted the intravascular or interstitial compartment, or both, which could have lowered blood pressure in patients who were likely to be sensitive even to small changes because of impaired cardiovascular reflexes. This may account for their low waking blood pressure, which is the opposite of what normally occurs. ${ }^{5}$

To determine the relation between overnight fluid loss and blood pressure we used the vasopressin analogue desmopressin, which has considerably greater antidiuretic activity but minimal pressor activity when compared with vasopressin (antidiuretic to pressor ratio of 2000-3000:1). ${ }^{6}$ Desmopressin was an effective antidiuretic, as there was a gain in weight of over $1.5 \mathrm{~kg}$, but there were no signs overnight secretion of sodium but increased it, suggesting that combination with fludrocortisone or salt supplementation, or both, may be needed. It is unlikely that desmopressin has direct pressor effects in patients with supersensitivity to vasopressor drugs ${ }^{1011}$ as the reverse, hypotension, has been reported in patients given desmopressin intravenously. ${ }^{12}$

The beneficial results that we observed suggest that there may be a therapeutic role for long term tratment with desmopressin, as indicated by preliminary studies with intranasal desmopressin. Patients should be monitored carefully, however, especially in the early stages, as exaggerated sensitivity may cause oliguria and hyponatraemia.

We thank the Brain Research Trust and the Wellcome Trust for their support. DFdaC is a Prophit scholar of the Royal College of Physicians, London.

\section{References}

1 Mann S, Altman DG, Raftery EB, Bannister R. Circadian variation of blood pressure in autonomic failure. Circulation 1983;68:477-83.

2 Bannister R. Introduction and classification. In: Bannister R, ed. Autonomic failure. A textbook of clinical disorders of the autonomic nervous system. Oxford: Oxford University Press, 1983:1-13. 3 Da Costa DF, Bannister R, Mathias CJ. Observations on postprandial hypotension and its causation in autonomic failure. $\mathcal{F}$ Neurol Neurosurg Psychiatry 1985;48:604

4 Davidson C, Smith D, Morgan DB. Diurnal pattern of water and electrolyte excretion and body weight in idiopathic orthostatic hypotension. Am f Med 1976;61:709-15.

5 Millar-Craig MW, Bishop CN, Raftery EB. Circadian variation of blood pressure. Lance 1978;i:795-7.

6 Richardson DW, Robinson AG. Desmopressin. Ann Intern Med 1985;103:228-39.

7 Wilcox CS. Body fluids and renal function in autonomic failure. In: Bannister R, ed. Autonomic failure. A textbook of clinical disorders of the autonomic nervous system. Oxford: Oxford University failure. A textbook of

8 Williams TDM, Lightman SL, Bannister R. Vasopressin secretion in progressive autonomic failure: evidence for defective afferent cardiovascular pathways. I Neurol Neurosurg Psychiatry 1985; 48:225-8.

9 Lang RE, Tholken H, Ganten D, Luft FC, Ruskoaho H, Unger T. Atrial natriuretic factor-a circulating hormone stimulated by volume loading. Nature 1985;314:264-6.

10 Mathias CJ, Matthews WB, Spalding JMK. Postural changes in plasma renin activity and response to vasoactive drugs in a case of Shy-Drager syndrome. I Neurol Neurosurg Psychiaty 1977;2:147-56

11 Bannister R, Davies IB, Holly E, Rosenthal T, Sever P. Defective cardiovascular reflexes and supersensitivity to sympathomimetic drugs in autonomic failure. Brain 1979;102:163-76.

12 Derkx FH, Man in't Veld AJ, Jones R, Reid JL, Schalekamp MADH. DDAVP (1-desamino-8-darginine vasopressin): an antagonist of the pressor action of endogenous vasopressin? Journal of Hypertension 1983;1(suppl 2):58-61.

(Accepted 19 May 1986) 